\title{
HHEX Gene
}

National Cancer Institute

\section{Source}

National Cancer Institute. HHEX Gene. NCI Thesaurus. Code C114957.

This gene is involved in transcriptional modulation. 